\title{
Assessment of Antioxidant Indices after incorporating Crude Oil Contaminated Catfish and African Nutmeg (Monodora Myrstica) Extracts into Rat Diet
}

\author{
*OKPOGHONO, J; GEORGE, BO; ACHUBA, FI \\ Department of Biochemistry, Faculty of Science, Delta State University, Abraka, \\ Delta State, Nigeria. *Corresponding author: okpoghono@gmail.com +2348064618605
}

\begin{abstract}
This study was carried out to assess the antioxidant status of rats fed with diets of catfish contaminated by crude oil and aqueous, ethanol and diethyl ether extracts of Africa nutmeg. Thirty albino rats of weight 180 to $200 \mathrm{~g}$ were used for the experiment. They were divided into six groups of five rats each as follows: group 1: control, group 2: rats fed crude petroleum oil contaminated catfish diet (CPO-CCD) only, group 3: CPOCCD plus tween 80, group 4, 5, and 6 were given CPO-CCD and then treated with M. myristica water extract (MWE), M. myristica ethanol extract (MEE) and M. myristica diethyl ether extract (MDEE). The experiment lasted four weeks. The results showed significant $(\mathrm{p}<0.05)$ decrease in blood reduced glutathione $(\mathrm{GSH})$, blood oxidised glutathione (GSSG), superoxide dismutase (SOD), catalase (CAT) and increase malondialdehyde (MDA) level in the liver, kidney and brain of rats fed CPO-CCD only and CPO-CCD + tween 80 compared to the control. Administration of MWE, MEE and MDEE to the rats fed CPO-CCD significantly $(\mathrm{p}<0.05)$ increased the level of blood GSH, blood GSSG, SOD, CAT and decrease MDA level in the liver, kidney and brain when compared with the CPO-CCD only and CPO-CCD + Tween 80. No significant difference was observed in the blood GSH: GSSG ratio in all the experimental groups. In conclusion, $M$. myristica extracts exhibited beneficial effect on the antioxidant status by evading the oxidative insults elicited by the CPO-CCD intoxication in the various tissues.
\end{abstract}

DOI: https://dx.doi.org/10.4314/jasem.v22i2.7

Copyright: Copyright $\odot 2018$ Okpoghono et al. This is an open access article distributed under the Creative Commons Attribution License (CCL), which permits unrestricted use, distribution, and reproduction in any medium, provided the original work is properly cited

Dates: First received 06 January 2018; Received in revised form 07 January 2018; Accepted 10 February 2018

Keywords: Petroleum, Diet, Antioxidants Indices, Monodora Myrstica, Africa nutmeg

Exposure to crude oil pollution leads to the formation of free radicals (Won et al., 2016). Free radical is the most common reactive oxygen species in human (Georgewill and Nwankwoala, 2008). Once polyaromantic hydrocarbons enter the body of a living organism, each are metabolized to form highly reactive molecules such as diol epoxides that are polyromantic hydrocarbons intermediate metabolites that causes oxidative stress (Ekperusi and Aigbodion, 2015; Penning, 2014).

Reduced glutathione a multifunctional intracellular non-enzymatic antioxidant is well known to be the major thiol-disulphide redox buffer of the cell (Swaran, 2009). Oxidized glutathione is accumulated inside the cells and the ratio of GSH/GSSG is a good measure of oxidative stress of an organisms (Swaran, 2009). Superoxide dismutase is an enzyme that alternately catalyzes the dismutation of the superoxide radical into either ordinary molecular oxygen or hydrogen peroxide (Hayyan et al., 2016). Catalase is also an enzyme. The name catalase was given to the enzyme owing to its catalatic action on the hydrogen peroxide. Antioxidant enzymes can be inactivated by lipid peroxides (Alantary et al., 2014;
Hamza and Al-Harbi, 2015). Subchronic exposure of rats to crude oil, decreases catalase activities in the tissues (Nwaogu et al., 2011). Several studies have shown that, direct exposure to crude oil can disrupt antioxidant status in serum, liver, kidney and brain (Adedara et al., 2012; Ebokaiwe and Farombi, 2016). Monodora myristica is a spice commonly consumed in the Niger Delta part of Nigeria especially by the Itsekiri, Urhobo and Ukwuani people of Delta State. The seeds of $M$. myristica smell attractive, possess antioxidant properties and can be used in pharmaceutical industries (Talalaji, 1999). The present study aimed to assess the effect of $M$. myristica extracts in rats given diet containing catfish polluted with crude petroleum oil by evaluating some antioxidant indices such as reduced and oxidised GSH, CAT, SOD and lipid peroxidation level.

\section{MATERIALS AND METHODS}

Preparation of the spice (Monodora myristica) extracts: M. myristica was obtained from Obiaruku main market, Ukwuani Local Government Area (LGA), Delta State. The spice was then later 
identified at the Department of Botany, Delta State University, Abraka, Delta State. The spice was sundried to constant weight then crushed into fine particles using blender for at high speed. One hundred grams of the powdered spice was extracted with $500 \mathrm{ml}$ of the respective solvent (hot water (60 ${ }^{\circ} \mathrm{C}$ ), ethanol (95\% v/v), and diethyl ether, $95 \% \mathrm{v} / \mathrm{v}$ ) and allowed to stand for $48 \mathrm{hrs}$. The mixture was filtered using a clean muslin cloth. The filtrate was evaporated to dryness using rotary evaporator attached to a vacuum pump. The extracts were stored in refrigerator $\left(-4^{\circ} \mathrm{C}\right)$ until required.

Crude petroleum oil pollution and diet preparation: The crude petroleum oil was gotten from the Nigerian National Petroleum Cooperation (NNPC), refinery, Warri Delta State, Nigeria. Fifty catfish (with length between $20-25 \mathrm{~cm}$ and weight between 250-300 g) was obtained from commercial farm, and allowed to acclimatize for 7 days for the experiment. The catfish was divided into two groups; group 1: control; contained twenty-five catfish which was cultured in plastic aquaria with $30 \mathrm{~L}$ borehole water for four weeks. Group 2: also contained twenty-five catfish which was cultured in plastic aquaria containing $30 \mathrm{~L}$ borehole water and then polluted with crude petroleum oil, $(823.3 \mu \mathrm{l} / \mathrm{L})$ as described by Ikeogu et al. (2013) for a period of four weeks. At the end of the experimental period of 4 weeks, the catfish was harvested then dried at $40{ }^{\circ} \mathrm{C}$ in an electric oven, and used as source of protein in the preparation of diet for the experimental rats (Sunmonu and Oloyede, 2007). The diet for each group was prepared by mixing known quantities of sources of each food class comprising: protein (25 $\%)$, corn starch (52\%), groundnut oil (4\%), maize cob (4\%), granulated refined sugar $(10 \%)$ and vitamin/mineral mixture $(5 \%)$. The food components were mixed together and then made into pellets, and used to feed the rats.

Experimental rats: Thirty male albino Wistar rats were used for the study. They were allowed to acclimatize for two weeks under laboratory condition. The rats had free access to water and standard growers mash diet. They were maintained in accordance to the guide for care and use of laboratory animals (NIH, 1985). The experimental rats were divided into six groups of five rats; group 1: control, group 2: CPO-CCD only, group 3: CPO-CCD plus 1 $\mathrm{ml} / \mathrm{kg} \mathrm{b}$. wt. of $1 \%$ tween 80 , group 4: CPO-CCD plus $200 \mathrm{mg} / \mathrm{kg}$ b. wt. of MWE, Group 5: CPO-CCD plus $200 \mathrm{mg} / \mathrm{kg} \mathrm{b}$. wt. of $\mathrm{MEE}$ and group 6: CPOCCD plus $200 \mathrm{mg} / \mathrm{kg}$ b. wt. of MDEE. Rats in all the groups $(1-6)$ received tap water daily throughout the experiment. The administration of CPO-CCD and the extracts orally was carried for four weeks.

Blood collection and preparation of tissue homogenate: The rats were sacrificed after 24 hours fast on the last day. The blood was collected by cardiac puncture using hypodermic syringe and needle, and was placed in anticoagulant tubes. The organs were harvested immediately. One gram of various tissue (liver, kidney and brain) were homogenized in $10 \mathrm{ml}$ of normal saline and then centrifuged at 2,500 revolution per minutes for 15 minutes to obtain the supernatant which was immediately used for biochemical analysis.

Biochemical Analysis: Estimation of blood GSH/GSSG (reduced/oxidized glutathione) ratio: Blood GSH/GSSG was estimated using the enzymatic method described by Tietze (1976).

GSSG sample preparation: Thirty microliters $(30 \mu \mathrm{L})$ of thiol-scavenging reagent (50 mg 1- methyl pyridinium trifluoromethane sulphonate) was added to a micro-centrifuge tube and $100 \mu \mathrm{L}$ of whole blood was carefully added to the bottom of the centrifuge tube and mixed gently. GSSG sample 130 $\mu \mathrm{L}$ was incubated at room temperature for 5-10 minutes. Thereafter $270 \mu \mathrm{L}$ of ice-cold $5 \%$ metaphosphoric acid (MPA) was added to the tube and centrifuged at $1000 \mathrm{x} g$ and $4{ }^{0} \mathrm{C}$ for 10 minutes. The supernatant $(50 \mu \mathrm{L})$ was added to $700 \mu \mathrm{L}$ of assay buffer (phosphate buffer, $2 \mathrm{M}, \mathrm{pH} 8$ ) in a new micro-centrifuge tube, this was placed on ice until used.

GSH sample preparation:Fifty microliter $(50 \mu \mathrm{L})$ of whole blood was added to the bottom of a microcentrifuge tube and then mixed. Thereafter $350 \mu \mathrm{L}$ of ice-cold $5 \%$ MPA was added to the micro-centrifuge tubes and centrifuged at $1000 \times \mathrm{g}$ in $4{ }^{0} \mathrm{C}$ for 10 minutes. Then, $25 \mu \mathrm{L}$ of the supernatant was added to $1.5 \mathrm{~mL}$ of assay buffer in a new micro-centrifuge tubes and this was placed on ice until required.

Procedure for blood GSH and GSSG; Two hundred microliters $(200 \mu \mathrm{L})$ of samples and blank were added to $200 \mu \mathrm{L}$ of the 5,5'-dithio-bis-[2-nitrobenzoic acid] (DTNB) solution in respective test-tubes, then $200 \mu \mathrm{L}$ of the reductase solution (recombinant glutathione reductase) was added immediately then mixed. These were allowed to incubate at room temperature for 5 minutes, then $200 \mu \mathrm{L}$ of $2 \mathrm{mg} / \mathrm{mL}$ NADPH solution was added to the test tubes. The absorbance were read and recorded at $412 \mathrm{~nm}$. 
Standard curve: After preparing $1 \mathrm{mM}$ stock solution of GSH /GSSG, different concentrations were prepared. From each of the GSH/GSSG dilution, 200 $\mu \mathrm{l}$ was added to $2300 \mu \mathrm{l}$ of $0.2 \mathrm{M}$ phosphate buffer $\mathrm{pH}$ 7.6. This was followed by the addition $500 \mu \mathrm{l}$ of 1 $\mathrm{mM}$ DTNB. The resulting mixture was well shaken and incubated for five minutes. After the incubation period, absorbance of each mixture was recorded at $412 \mathrm{~nm}$. DTNB blank was prepared by adding $500 \mu \mathrm{l}$ DTNB to $2500 \mu \mathrm{l}$ phosphate buffer $\mathrm{pH}$ 7.6. Absorbance of the DTNB blank was also taken at 412 $\mathrm{nm}$. The real absorbance of each mixture was obtained by subtracting absorbance of DTBN blank from absorbance of each of the mixture. The concentration of GSSG is much lower in the reaction mixture compare to GSH. Standard calibration curve was plotted separately using $0,0.50,0.75,1.0$, and $1.50 \mu \mathrm{M}$ GSSG, and $0,1.0,1.5,2.0$, and $3.0 \mu \mathrm{M}$ GSH.

Conc. of GSH/GSSG ratio (units/ml)

$$
=\mathrm{GSH}-2 \mathrm{GSSG} / \mathrm{GSSG}
$$

Estimation of tissue reduced glutathione: The reduced glutathione concentration in the liver, kidney and brain were estimated using the method of Ellman (1959). Zero point five millilitres $(0.5 \mathrm{ml})$ of tissue homogenate was added $2 \mathrm{ml} 10 \%$ TCA and centrifuged. One millilitre $(1 \mathrm{ml})$ of supernatant was treated with $0.5 \mathrm{ml}$ of Ellman's reagent and $3 \mathrm{ml}$ of phosphate buffer. The colour developed was read at $412 \mathrm{~nm}$. A series of standard were treated in similar manner along with a blank containing $3.5 \mathrm{ml}$ of buffer.

Determination of superoxide dismutase activity: The activity of SOD in the liver, kidney and brain were assayed using the method of Misra and Fridovich (1972). The assay was carried out by adding $0.2 \mathrm{ml}$ of the supernatant to $2.5 \mathrm{ml}$ of $0.05 \mathrm{M}$ carbonate buffer, $\mathrm{pH}$ 10.2. The reaction started by the addition of $0.3 \mathrm{ml}$ freshly prepared epinephrine as the substrate to the buffer supernatant mixture and quickly mixed by inversion. The reference cuvette contained $2.5 \mathrm{ml}$ of the buffer; $0.3 \mathrm{ml}$ of the substrate and $0.2 \mathrm{ml}$ of distilled water. The increase in absorbance at $480 \mathrm{~nm}$ due to the adrenochrome formed was monitored every 30 seconds for 120 seconds.

Determination of catalase activity: The method of Kaplan et al. (1972) was adopted for the assay of liver, kidney and brain catalase activity. Two millilitres $(2 \mathrm{ml})$ of $\mathrm{H}_{2} \mathrm{O}_{2}$ was added to $1 \mathrm{ml}$ of sample in the reaction cuvette. Absorbance was read at $360 \mathrm{~nm}$ for 70 seconds. The reference cuvette contained $2 \mathrm{ml} \mathrm{H} \mathrm{H}_{2} \mathrm{O}_{2}$ and $1 \mathrm{ml}$ of water. The disappearance of hydrogen peroxide was calculated using the Molar extinction co- efficient, $\varepsilon=39.4 \mathrm{M}^{-1}$ $\mathrm{cm}^{-1}$.

Determination of lipid peroxidation:Lipid peroxidation in form of malondialdehyde (MDA) were determined in the liver, kidney and brain by using the method of Buege and Aust (1978). One millilitre of the sample was added to $2 \mathrm{ml}$ of TCATBA-HCL reagent [0.37\% Thioarbituric acid (TBA), $15 \%$ TCA and $0.24 \mathrm{~N}$ Hydrochloric acid $(\mathrm{HCl})$ ] (1:1:1 ratio). The tube was stoppered loosely and immersed in boiling water for 15 minutes and swirled slightly at intervals. The mixture was cooled and centrifuged for 10 minutes at 5000 RPM. The absorbance was read at $532 \mathrm{~nm}$ using the reagent blank. Lipid peroxidation in units/g of wet tissue was calculated with a molar extinction co-efficient of 1.56 x $10^{5} \mathrm{M}^{-1}$

Statistical Analysis: Descriptive statistic was carried out on the data obtained from each parameter. The results were expressed as mean \pm SD. The significant differences between groups were analyzed using one way analysis of variance (ANOVA) and least significant difference (LSD). The SPSS-PC programme package (version 22.0) was used for statistical analysis. A significant threshold of $\mathrm{p}<0.05$ was regarded statistically significance between the test and control group for the analysis.

\section{RESULTS AND DISCUSSION}

Alterations of blood GSH, GSSG and GSH: GSSG ratio of rats fed CPO-CCD treated with different extracts of $M$. myristica are shown in Table 1 . Significant $(\mathrm{p}<0.05)$ decrease level of blood GSH and GSSG were observed in rats fed CPO-CCD only and CPO-CCD + tween 80 when compare with control. Treatment of rats fed CPO-CCD with MWE, MEE and MDEE showed significant $(\mathrm{p}<0.05)$ increase the level of blood GSH and GSSG. The reduction in GSH and GSSG levels could be a compensatory mechanism by which the rats fed the formulated feed mixed with crude oil contaminated catfish to overcome the effect of the oxidant stress caused by free radicals produced by crude petroleum oil. The is in line with the findings of Shang et al. (2016), indicating that the decrease in GSH to GSSG ratio in the blood implies that oxidative stress occurred in the distant organs due to crude petroleum oil induced toxicity. No significant difference were observed in the blood GSH, GSSG and GSH : GSSG ratio when rats fed $\mathrm{CPO}-\mathrm{CCD}$ only were compared with rats fed CPO-CCD + tween 80 . These results 
may be considered as pathological evidences to confirm the nontoxic effect of tween 80 as previously reported (Rowe, 2009). The level of GSH, SOD and CAT activity in the liver, kidney and brain of rats fed CPO-CCD treated with extracts of M. myristica are presented in Table 2, 3 and 4 respectively. No significant difference was seen in GSH level in the brain of all the experimental groups. The reduction in GSH level in the kidney and liver of rats fed CPOCCD only (Table 2) may be due to the decrease in the activity of the hepatic glutamate-cysteine ligase (a key enzyme responsible for glutathione synthesis) (Shang et al. (2016). The depletion in brain GSH level of rats fed CPO-CCD may lead to increased production of superoxide, hydroxyl radicals, and hydrogen peroxide, because there is no known enzymatic defense against hydroxyl radicals (Dringen, 2000), making GSH the only compound capable of scavenging these radicals in the brain.

Table 1: Blood GSH, GSSG and GSH: GSSG ratio of rats fed CPO-CCD treated with extracts of $M$. myristica

\begin{tabular}{lllll}
\hline Groups & $\begin{array}{c}\text { Blood GSH } \\
\text { (units/ml) }\end{array}$ & $\begin{array}{c}\text { Blood GSSG } \\
\text { (units/ml) }\end{array}$ & $\begin{array}{c}\text { Blood GSH: } \\
\text { GSSG ratio }\end{array}$ \\
\hline 1: & Control & $1.81 \pm 0.04^{\mathrm{a}}$ & $0.72 \pm 0.03^{\mathrm{a}}$ & $0.99 \pm 0.02^{\mathrm{a}}$ \\
2: & CPO-CCD only & $0.42 \pm 0.02^{\mathrm{b}}$ & $0.11 \pm 0.07^{\mathrm{b}}$ & $0.80 \pm 0.05^{\mathrm{a}}$ \\
3: & CPO-CCD + Tween 80 & $0.42 \pm 0.06^{\mathrm{b}}$ & $0.12 \pm 0.05^{\mathrm{b}}$ & $0.83 \pm 0.04^{\mathrm{a}}$ \\
4: & CPO-CCD + MWE & $1.09 \pm 0.05^{\mathrm{a}}$ & $0.53 \pm 0.01^{\mathrm{a}}$ & $1.00 \pm 0.01^{\mathrm{a}}$ \\
5: & CPO-CCD + MEE & $1.41 \pm 0.32^{\mathrm{a}}$ & $0.56 \pm 0.01^{\mathrm{a}}$ & $1.01 \pm 0.02^{\mathrm{a}}$ \\
6: & CPO-CCD + MDEE & $1.63 \pm 0.10^{\mathrm{a}}$ & $0.61 \pm 0.02^{\mathrm{a}}$ & $1.00 \pm 0.01^{\mathrm{a}}$ \\
\hline
\end{tabular}

Values are given in mean $\pm S D . n=5$. Mean values with different superscript letter in the same column differ significantly at $p<0.05$.

Table 2: GSH level in the liver, kidney and brain of rats fed CPO-CCD treated with extracts of M. myristica

\begin{tabular}{|c|c|c|c|c|}
\hline \multirow{2}{*}{\multicolumn{2}{|c|}{ Groups }} & \multicolumn{3}{|c|}{ GSH (units/g wet tissue) } \\
\hline & & Liver & Kidney & Brain \\
\hline 1: & Control & $7.19 \pm 0.99^{\mathrm{a}}$ & $6.54 \pm 0.05^{\mathrm{a}}$ & $3.33 \pm 0.47^{\mathrm{a}}$ \\
\hline 2: & CPO-CCD only & $3.36 \pm 0.94^{\mathrm{b}}$ & $2.24 \pm 0.79^{\mathrm{b}}$ & $1.01 \pm 0.05^{\mathrm{a}}$ \\
\hline 3: & CPO-CCD + Tween 80 & $2.34 \pm 0.73^{b}$ & $1.76 \pm 0.57^{\mathrm{b}}$ & $2.81 \pm 0.08^{\mathrm{a}}$ \\
\hline 4: & CPO-CCD + MWE & $3.46 \pm 0.54^{\mathrm{b}}$ & $3.31 \pm 0.66^{b}$ & $2.36 \pm 0.16^{\mathrm{a}}$ \\
\hline 5: & CPO-CCD + MEE & $3.96 \pm 0.09^{b}$ & $4.29 \pm 0.19^{\mathrm{b}}$ & $2.20 \pm 0.16^{\mathrm{a}}$ \\
\hline 6: & CPO-CCD + MDEE & $6.25 \pm 0.58^{\mathrm{a}}$ & $5.31 \pm 0.29^{\mathrm{a}, \mathrm{b}}$ & $2.64 \pm 0.08^{\mathrm{a}}$ \\
\hline
\end{tabular}

Values are given in mean $\pm S D . n=5$. Mean values with different superscript letter in the same column differ significantly at $p<0.05$.

Table 3: Changes in superoxide dismutase activity in the liver, kidney and brain of rats fed CPO-CCD treated with extracts of $M$.

\begin{tabular}{lllll}
\multicolumn{5}{c}{ myristica } \\
Groups & & \multicolumn{4}{l}{ SOD (units/g wet tissue) } \\
Liver & Kidney & Brain \\
\hline $1:$ & Control & $89.41 \pm 19.16^{\mathrm{a}}$ & $86.41 \pm 14.28^{\mathrm{a}}$ & $73.50 \pm 6.52^{\mathrm{a}}$ \\
2: & CPO-CCD only & $57.36 \pm 6.12^{\mathrm{b}}$ & $55.07 \pm 8.00^{\mathrm{b}}$ & $40.28 \pm 3.15^{\mathrm{b}}$ \\
$3:$ & CPO-CCD + Tween 80 & $56.07 \pm 14.40^{\mathrm{b}}$ & $54.46 \pm 3.03^{\mathrm{b}}$ & $40.90 \pm 2.67^{\mathrm{b}}$ \\
$4:$ & CPO-CCD + MWE & $66.43 \pm 6.98^{\mathrm{c}}$ & $65.29 \pm 6.29^{\mathrm{c}}$ & $50.48 \pm 4.33^{\mathrm{c}}$ \\
$5:$ & CPO-CCD + MEE & $78.11 \pm 6.77^{\mathrm{d}}$ & $74.50 \pm 3.38^{\mathrm{d}}$ & $67.32 \pm 2.90^{\mathrm{d}}$ \\
6: & CPO-CCD + MDEE & $85.47 \pm 3.58^{\mathrm{a}}$ & $82.41 \pm 1.42^{\mathrm{a}}$ & $70.23 \pm 5.21^{\mathrm{a}}$ \\
\hline
\end{tabular}

Values are given in mean $\pm S D . n=5$. Mean values with different superscript letter in the same column differ significantly at $p<0.05$.

Table 4: Changes in catalase activity in the liver, kidney and brain of rats fed CPO-CCD treated with extracts of M. myristica.

\begin{tabular}{|c|c|c|c|c|}
\hline \multirow{2}{*}{\multicolumn{2}{|c|}{ Groups }} & \multicolumn{3}{|c|}{ CAT (units/g wet tissue) } \\
\hline & & Liver & Kidney & Brain \\
\hline 1: & Control & $74.28 \pm 10.19^{\mathrm{a}}$ & $70.18 \pm 8.65^{\mathrm{a}}$ & $64.26 \pm 5.94^{\mathrm{a}}$ \\
\hline 2: & CPO-CCD only & $46.53 \pm 12.62^{b}$ & $40.31 \pm 7.62^{b}$ & $35.71 \pm 3.92^{b}$ \\
\hline 3: & CPO-CCD + Tween 80 & $46.16 \pm 512^{\mathrm{b}}$ & $41.15 \pm 2.95^{\mathrm{b}}$ & $36.27 \pm 4.37^{\mathrm{b}}$ \\
\hline 4: & CPO-CCD + MWE & $55.31 \pm 10.19^{\mathrm{c}}$ & $52.28 \pm 3.47^{\mathrm{c}}$ & $45.49 \pm 3.64^{\mathrm{c}}$ \\
\hline 5: & CPO-CCD + MEE & $61.47 \pm 11.53^{\mathrm{d}}$ & $60.74 \pm 5.42^{d}$ & $50.39 \pm 5.99^{d}$ \\
\hline 6: & CPO-CCD + MDEE & $72.20 \pm 5.65^{\mathrm{a}}$ & $68.32 \pm 3.57^{\mathrm{a}}$ & $61.17 \pm 2.38^{\mathrm{a}}$ \\
\hline
\end{tabular}

Values are given in mean $\pm S D . n=5$. Mean values with different superscript letter in the same column differ significantly at $p<0.05$.

These findings are in line with the study of Aoyama et al. (2008) which suggested that the brain is vulnerable to oxidative stress in comparison with other organs. This is because it has lower SOD, CAT, and glutathione peroxidase; GPx activities, while it contains an abundance of lipids with unsaturated fatty acids that are targets of lipid peroxidation (Dringen, 2000). Furthermore, the brain GSH concentration is lower than those of the liver and kidney (Aoyama et al., 2008). The detoxification mechanisms promoted by enhanced glutathione production indicates the protective effects of MDEE, MEE and MWE. 
Rats fed with CPO-CCD only and CPO-CCD + Tween 80 showed significant $(\mathrm{p}<0.05)$ decrease in SOD and CAT activity in the liver, kidney and brain when compared to the control (Table 3 and 4). Administration of MWE, MEE and MDEE to CPOCCD rats significantly $(\mathrm{p}<0.05)$ increase the activity of SOD and CAT in the liver, kidney and brain when compare with the CPO-CCD only and CPO-CCD + Tween 80 respectively. The marked reduction in SOD activity of rats fed CPO-CCD and the enhanced SOD activity when $M$. myristica extracts was administered were in agreement with other studies (Nwaogu et al., 2011; Sunmonu and Oloyede, 2007). The inhibition of CAT activity during CPO-CCD induced toxicity may be due to the increased generation of reactive free radicals, which can lead to oxidative stress in the cells. The administration of MDEE, MEE and MWE inversed the catalase activity in the liver, kidney and brain tissues and thus enhancing the antioxidant defense against ROS. These findings are in collaboration with Oyinloye et al.(2016) who reported that M. myristica aqueous extract prevent lipid peroxidation and replenish hepatic antioxidant enzymes against cadmium induced liver tissue damage.

Figure 1, showed the level of MDA; malondialdehyde (end product of membrane lipid peroxidation) in the tissues (liver, kidney and brain) of rats fed CPO-CCD treated with extracts of $M$. myristica. Significant $(\mathrm{p}<0.05)$ increase were observed in MDA level in the tissues of rats fed CPO-CCD only and CPO-CCD + tween 80 when compared with the control.

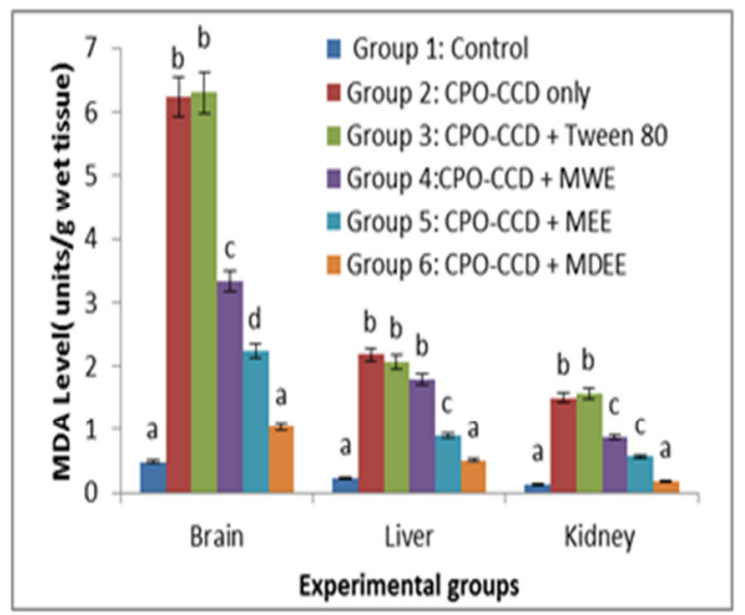

Fig 1: MDA level in the liver, kidney and brain of rats fed CPOCCD treated with different extracts of $M$. myristica. Bars represent mean values from five rats in each group. For each organ, bars with different superscript letter in the same column differ significantly at $\mathrm{p}<0.05$.
However, treatment of rats fed CPO-CCD with the different extracts significantly decreased the level of MDA as compared with that of the control. The excessive ROS generated during crude petroleum oil toxicity rapidly reacted with lipid membranes to initiate the lipid peroxidation chain reaction, resulting in lipid peroxyl radicals' formation (Ita and Edagha, 2016; Ujowundu et al., 2012; Nwaogu et al., 2011). The elevation of lipid peroxidation in rats administered crude petroleum oil has been previously reported (Sunmonu and Oloyede, 2007), which is in this study. In the present study, the lower MDA levels in the tissues of rats fed CPO-CCD plus $M$. myristica extracts, apparently indicates the antioxidative protective role of $M$. myristica extracts against CPO-CCD induced damage on cell membranes. Moreover, MDEE revealed a strong inhibitory ability towards lipid peroxidation when compare with MEE and MWE.

Conclusion: The results from this study suggests that, the protective effect of $M$. myristica extracts against tissues damage and lipid peroxidation as evident in the maintenance of normal levels of the antioxidant enzymes in CPO-CCD fed rats. However, the aqueous, ethanol and diethyl ether extracts of $M$. myristica are promising candidates for development of antioxidant drugs which supports its usage for medicinal purposes. Further research works are in progress to isolate and characterize the active components of the extracts that may be responsible for the protective activity.

\section{REFERENCES}

Adedara, IA; Teberen, R; Ebokaiwe, AP; Ehwerhemuepha, T; Farombi, EO (2012). Induction of oxidative stress in liver and kidney of rats exposed to Nigerian bonny light crude oil. Environ. Toxicol. 27:372-379.

Alantary, AK; Rezk, MY; Soliman, KEA (2014). Protective effect of ghrelin on paracetamol induced acute hepatotoxicity in rats. J. Physiol. Pathophysiol. 5(2): 7-14.

Aoyama, K; Watabe, M; Nakaki, T (2008). Regulation of neuronal glutathione synthesis. $J$. Pharm. Sci. 108: 227 - 238.

Buege, JA; Aust, SD (1978). Microsomal lipid peroxidation. Methods in Enzymol. 52: 302-305

Dringen, R (2000). Metabolism and functions of glutathione in brain. Progress Neurobiol. 62: 649-671 
Ebokaiwel, AP; Farombi, EO (2016). Impact of heavy metals in food products from crude oil polluted area of Nigeria in testicular functions of Wistar rats. J. Appl. Life Sci. Inter. 5(2): 1-11

Ekperusi, OA; Aigbodion, FI (2015).Bioremediation of petroleum hydrocarbons from crude oilcontaminated soil with the earthworm: Hyperiodrilus africanus. Biotechnol. 5: 957-965.

Ellman, GL (1959). Tissue sulfhydryl groups. Archives Biochem. Biophy. 82:70-77.

Georgewill, OA; Nwankwoala, RNP (2008). Interaction of crude oil with alpha-tocopherol: Protection of crude oil lethal effects on weights and reproductive hormones through antioxidation. Afr. J. Appl. Zoo. Environ. Biol. 10: 65-69.

Hamza, RZ; Al-Harbi, SM (2015). Amelioration of paracetamol hepatotoxicity and oxidative stress on mice liver with silymarin and Nigella sativa extract supplements. Asian Pacific J. Tropical Biomed. (7): 521-531.

Hayyan, M; Hashim MA; AlNashef, IM (2016). Superoxide ion: generation and chemical implications. Chem. Rev. 116 (5): 3029-3085.

Ikeogu, CF; Nsofor, CI; Igwilo, IO (2013). Toxicity of lead nitrate and crude oil on the growthof the African catfish Clarias gariepinus. Inter. J. Agric. Biosci. 2(6): 337-339

Ita, SO; Edagha, IA (2016). Renal protective effect of antioxidant vitamins $\mathrm{C}$ and $\mathrm{E}$ against crude oilinduced nephrotoxicity. Merit Res. J. Med. Medic. Sci. 4(9):425- 431.

Kaplan, A; Dembiec, D; Cohen, G; Marcus J (1972). Measurement of catalase activity in tissue extracts. Analy. Biochem. 34: 30-38.

Misra, HP; Fridovich, I (1972). The role of superoxide anion in the autooxidation of epinephrine and a sample assay for superoxide dismutase. J. Biol. Chem. 247: 3170-3175.

National Institutes of Health; NIH (1978). Guide for the care and use of laboratory animals (revised). NIH Publication No. 82-83.

Nwaogu, LA; Igwe, CU; Ujowundu, CO; Arukwe, U; Ihejirika, CE; Iweke, AV (2011). Biochemical changes in tissues of albino rats following subchronic exposure to crude oil. J. Res. Biol. 8: 617-623

Oyinloye, BE; Adenowo, AF; Osunsanmi, FO; Ogunyinka, BI; Nwozo, SO; Kappo, AP (2016). Aqueous extract of Monodora myristica ameliorates cadmium-induced hepatotoxicity in male rats. Springerplus 5: 641-648

Penning, TM (2014). Human aldo-keto reductases and the metabolic activation of polycyclic aromatic hydrocarbons. Chemical Res. Toxicol. 27:1901-1917

Rowe, RC; Sheskey, PJ; Quinn, ME (2009). Handbook of Pharmaceutical Excipients 6th edition Pharmaceutical Press, London, England. Pp. 551-553

Shang, Y; Siow, YL; Isaak, CL; Karmin, O (2016). Down regulation of glutathione biosynthesis contributes to oxidative stress and liver dysfunction in acute kidney injury. Oxid. Med. Cellular Long. 16:1-16.

Sunmonu, TO; Oloyede, OB (2007). Biochemical assessment of the effects of crude oil contaminated catfish (Clarias gariepinus) on the hepatocytes and performance of rat. Afr. J. Biochem. Res. 1 (5): 083-089

Swaran, JSF (2009). Structural, chemical and biological aspects of antioxidants for strategies against metal and metalloid exposure. Oxid. Med. Cellular Long. 2:4:191-206.

Talalaji, SJ (1999). Essential oil from Monodora myristica grown in Ghana. West Afr. Pharm. 4: 64-65.

Tietz, NW (1976). Clinical guide to laboratory test. W.B. Saunders Co: Philadelphia. Page 487

Ujowundu, CO; Kalu, FN; Nwaoguikpe, RN; Okechukwu, RI; Ihejirika, CE (2012). The antioxidants potentials of Gongronemalatifolium on diesel petroleum induced hepatotoxicity. $J$. Appl. Pharm. Sci. 2(1): 90-94

Won, E; Kim, R; Kang, H; Kim, H; Hwang, DS; Han, J; Lee, YH; Hwang, UK; Lee, J (2016). Adverse effects, expression of the BkCYP3045C1 gene, and activation of the ERK signaling pathway in the water accommodated fraction-exposed rotifer. Environ. Sci. Technol. 50 (11): 6025-6035. 